\title{
The Common: 10 Years of Theoretical Practice
}

Nearly a decade ago, the common - understood here as the basis of social, political and economic coexistence - became the starting point for the project initiated by a group of young researchers who founded the scientific journal Theoretical Practice. When we published the first issue in the spring of 2010, one devoted to the concept of community, we could not have foreseen that just in a few years we would be able to entice so many people into the orbit of our collective reflection. We did not realize that our "theoretical practice" could constitute an ever-expanding, inclusive project in which so many and such varied groups of theorists would grow and argue with each other.

This communal experience came into being mainly because we were never interested in building an identity, a hermetic community; instead we have always emphasized a lively and dynamic process: commoning of concepts, co-thinking, communication and joint struggle for conditions enabling the constant expansion of these practices. Years later, it is in this idea and the practice of the common - which prefigures any communism worthy of its name - that we see the cornerstone on which the project and our collective are built on. And although it is impossible to do justice to the multiplicity of the collective activities that were carried out by people associated with Theoretical Practice over these ten years, one event certainly deserves mention.

The Polish edition of Commonwealth by Michael Hardt and Antonio Negri (2009), which was prepared by the editorial collective between 
2010 and 2012. Hardt and Negri's book contains a project of conceiving a radical and anti-capitalist theory and practice beyond the division into the private and the public, on the one hand, and beyond liberalism and socialism, on the other. It created a space for the common as a prefiguration of the politics of communism always present on the pages of Theoretical Practice. Common readings and endless polemics that took place during the subsequent seminars on the proposals of the Italian-American duo undoubtedly contributed to the further development of a common vocabulary underlying the multiplicity and heterogeneity of activities undertaken by the editorial collective. Even if today, in retrospect, the proposal of Hardt and Negri for many of us needs to be expanded, the direction indicated at its foundations does not lose any significance for us. We are still trying to create an increasingly inclusive interpretation of the common, which will not, however, assign value to some concepts at the expense of others.

The basic intuition behind the notion of the common has passed the test of time. The common has become synonymous with all those moments in Marxist theory that, while not falling into the ambush of modernity and its specific dialectics, remain faithful to the fundamental task and the communist promise of going beyond capitalist social relations. The creation of conditions for this movement is not the work of external intervention, but its possibility is immanent in the reality that demands transgression. Read through that prism, the common is precisely a form of antagonism to capitalist social relations and a prefiguration of what lies beyond them. This reasoning, although initiated by reading post-operaistas, ultimately convinces us of the vitality of Karl Marx's thought as the first theorist of the common in its antagonistic form to capitalism. In order to give this concept a tangible expression, let us, however, allow Marx to speak for himself:

In fact, however, when the limited bourgeois form is stripped away, what is wealth other than the universality of individual needs, capacities, pleasures, productive forces etc., created through universal exchange? The full development of human mastery over the forces of nature, those of so-called nature as well as of humanity's own nature? The absolute working-out of his creative potentialities, with no presupposition other than the previous historic development, which makes this totality of development, i.e. the development of all human powers as such the end in itself, not as measured on a predetermined yardstick? Where he does not reproduce himself in one specificity, but produces his totality? Strives not to remain something he has become, but is in the absolute movement of becoming? In bourgeois economics - and in the epoch of production to 
which it corresponds - this complete working-out of the human content appears as a complete emptying-out, this universal objectification as total alienation, and the tearing-down of all limited, one-sided aims as sacrifice of the human end-in-itself to an entirely external end (Marx 1973, 488).

The wealth of social relations that is hidden behind the commodity-form is ultimately nothing more than a synonym for the common (Holloway 2015). Therefore, we want to understand the commoning process from the title of this issue as a social practice that goes beyond particularisms and initiates the movement of building non-hierarchical relations. This movement is always a process of transforming: space, institutions, forms of cooperation, languages, affects or culture, but above all - ourselves. Thus, commoning is based on completely different ontological foundations than that of "ownership-oriented" identification, privatization or making something public, while functioning within the existing system and accruing benefit to it. It is a process that enhances the production of new subjectivities, spaces, practices and things that takes place in encounters based on mutuality and occurring beyond the horizon of private property and the market, as well as beyond the public and the state. It is in the strength of these interactions that we see a place for the emergence of the space of the common and the germination of the seed of new, communist relations. At the same time, we are aware that this process is particularly susceptible to being intercepted by alien forces that are redirecting its energy towards activities governed by the logic of profit and identity. Therefore, we believe that in order to successfully resist the seizure of the common by capitalist and fascist forms of control and power, the movement of the common must not lose sight of the red horizon. As communing is not a way to reform the existing society, but an antagonistic form of its critique and a radical move beyond the rules of the game that govern the present political and economic order. We combine them, therefore, with the discovery of new opportunities, the occupation of territories still not included on the map of the capitalist status quo, and the creation of collective subjectivities across contemporary divisions.

Contemporary anti-communism, i.e. the regime of the multidimensional elimination of the common (from our memory, imagination and social reality), certainly does not help us to perform such a task, especially when it functions in the conditions of an individualistic ontology of neoliberalism. The individual described by Marx in the introduction on method in Grundrisse, the individual as the keystone of classical political economy, in which collective powers are transposed into individual

Therefore, we want to understand the commoning process from the title of this issue as a social practice that goes beyond particularisms and initiates the movement of building non-hierarchical relations. 
In an age when our collective powers are greater than ever, and our collective and planetary action is

more urgent and necessary than ever before, the power to resist these tendencies can only be provided by the horizon of the common, as well as by the accompanying practices of communization. agency and resourcefulness, turns out to be constantly gaining in strength, while remaining more and more dependent on the richness of social relations that lie at its base. It becomes all the more necessary to reverse this movement, since it erases the potential of the common and manages life through the competition that regulates individual behaviour traps social energy in the vicious cycle of exploitation. All this to prevent the constitution of subjectivities capable of facing the most pressing challenges of modern times: the crisis in the sphere of employment and production of the reserve army of labour, an ecological catastrophe or the intensification of chauvinistic attitudes. In an age when our collective powers are greater than ever, and our collective and planetary action is more urgent and necessary than ever before, the power to resist these tendencies can only be provided by the horizon of the common, as well as by the accompanying practices of communization.

In this issue, we present a variety of articles that tackle precisely the question of possible transformative practices and spaces that hold the potential for creating non-hierarchical relations. The authors - each in a different context and manner - present their thoughts on the communizing efforts and many challenges posed by the current state of things, which they have to contend with. Ewa Majewska, by asking the question "Precarity and gender. What's love got to do with it?", undertakes an investigation into the transformative role that love can play in unleashing that productive forces that are dormant in the extant patriarchal social reality. In doing so, she proposes a genealogy of love - the author eloquently analyses varied theoretical iterations, both Marxist and feminist, historical movements, and geopolitical backgrounds, in which a revolutionary concept of love can be glimpsed. This genealogy provides a counterbalance to a heteronormative, romantic, and privatized vision of law, simultaneously giving a foothold for the postulated sublation of this vision. As Majewska argues, "love should thus be seen as an inspiration, a tool and a motivation, as well as a toolbox for action, not flattened to its commodified, profit-oriented or traditional, romantic versions." In this capacity, love closely ties in with solidarity and extends to the many bonds we form as interdependent social beings. Love understood in this way has a role to play in overcoming the current inequalities in affective labor and ever-present precarity, hence aiming towards realizing a communizing mode of togetherness. Although Magdalena Popławska's explorations in "Towards producer-consumer cooperation” proceed from very different grounds - the author takes on an inquiry into the social movements behind the alternative food networks and demands for food 
sovereignty - she also examines ventures geared towards more equal and communal relations. The description of transformative agroecology and many cooperatives serves to uncover the tenets behind the effort to go beyond industrialized and capital-driven food production. The focus on knowledge (often localized) exchange, mutual education, creating sustainability, and meeting the community's needs, first and foremost cause agroecological practices to "become expressions of care, as well as acts of resistance, manifested in everyday, tangible activities, and often associated with the space identified as 'home'."

The other presented articles require us to shift perspective - they draw our attention to mechanisms that create divisions within community and dissolve shared bonds. Nina Seiler in "March minusivity: Strategies of immunising and counter-immunising in the atmosphere of the Polish 1968" presents a discussion focused on the concept of minusivity as a potent tool for perceiving the process of induced distrust and the permeation of hostility throughout society. By looking into Polish literature and films, she proves that "the effects of an atmosphere of minusivity - the need to immunise against a threatening commonality - are thus autoimmunitarian reactions that cut into the immunising subject's very own flesh, destroying its sociality." Alongside this state of non-sociality there exists however a counter-measure, which is identified as a specific kind of commoning - one that works from within being-in-minus - that proves to be an apt way of counteracting its detrimental effects and rendering its power null. Aleksander Kopka, in turn, engages in a philosophically-oriented discussion around the concepts of grievability and mourning developed by Judith Butler and Jacques Derrida. In "Mourning and Grievability. Several Remarks on Judith Butler's Politics of Living Together", politics and ontology are investigated from a particular angle - the question of what exactly living together entails. Following the role that coming to terms with an imminent end to life plays within the community, author remarks on various implications it has for our co-existence. In this, he highlights the inequality hidden in the differing levels of precariousness and the vulnerability people are exposed to. The question of grievability has two purposes - it exposes the inner workings of biopolitics while simultaneously unveiling the new meaning of togetherness: "In living together, we challenge the existing norms and social bonds, cohesiveness or coherence of a socius, and at the same time, the phantasm of symbiotic or fusional life, the very concept of life, and the ontological arrest of being-together."

In line with the main topic of this issue and to celebrate the 10th anniversary of our journal, we have invited our long-lasting collaborators 
and comrades to reflect once again on the concept of the common and its possible futures. Therefore, the next part of this publication gathers five voices, which attempt to tackle problems crucial for the future of the politics of the common. These problems revolve around the following questions: a) what is the most important aspect of the current struggles for the common?; b) what are the biggest challenges for the commonist politics of the future?; and c) where in the ongoing struggles one may see a potential for scaling-up and spreading organisation based on the common? Most of the answers are formulated from the perspective of contemporary conjuncture, that is, remnants of the financial crisis and austerity, on the one hand, and the contemporary reproduction crisis accelerated by the Covid-19 pandemics, on the other. This is especially visible in Felipe Ziotti Narita's reply, for whom the double crisis of capitalism renders visible the commons as crucial for satisfying collective needs and purposes. Nonetheless, the challenge remains the same. How should we protect them from enclosures, extractivism and appropriation? In this context, he draws our attention to the social movements from which commonist politics may learn how to maintain the commons as sustainable and resilient. Starting from similar premises, Sandro Mezzadra argues that at the time of such crisis our efforts should be directed towards reinventing and reimagining welfare beyond the private-public mix, and be based on the common. This task is all the more urgent, as there is no going back to the western form of the welfare state, exposed as a product of specific material conditions grounded in industrial mass production of the Fordist era.

A glimpse into this process of reinventing welfare for our reproduction can be seen both in Eric Blanc's and Luis Martínez Andrade's replies. While Blanc draws our attention to the logic behind recent teachers strikes, especially in the United States, Andrade places his answer in the Latin-American context and introduces us to the struggles of communitarian feminism and indigenous movements. These struggles take the form of a fight for the common, as they are endowed with radical potentialities for the decommodification of sectors that are crucial for our reproduction and putting an end to the process of accumulation by dispossession. However, as Angela Dimitrakaki argues in her reply, the current pandemic moment not only reveals the persistence of the common but is at the same time a vivid testimony to the extent to which capital secured control over our lives by taking over the state and the media. To avoid repeating the defeats of the past a counter-power is needed, one that will reclaim the state and use it for the advancement of the politics of the common. Therefore, for 
Dimitrakaka, perhaps we have too hastily rejected the idea of a political party as a mean of mobilization and connecting the multiplicity of struggles for the common.

The last part of this publication is a discussion around Martin Müller's text "In Search of the Global East" (its Polish translation appeared in the previous issue of Praktyka Teoretyczna). It gathers together the voices of Polish researchers who responded to the invitation formulated in the conclusion of this article to think together about the Eastern question and new ways of making a further intervention in the Western-centric geopolitics of knowledge. These comments, while appreciating the theoretical strengths and political potential of Müller's proposal, draw attention to its shortcomings and contradictions. Magda Szcześniak emphasizes, for example, that in avoiding class analysis, Müller disregards the dynamics of social divisions within the societies of global capitalism, and thus overlooks "similar patterns of class distinction and reproduction across (...) North, South and East”. And only acknowledging their existence, she argues, can help us forge new forms of solidarity "amongst classes which are regularly oppressed by the dominant global capitalist order". Jan Sowa's remarks go in a similar direction. The author, in opposition to the strategic essentialism proposed by Müller, advocates for an anti-particularist approach - i.e. "alter-universalism" or "universalism of the subaltern". After all, as Sowa claims, our task is not to support the new version of the struggle between East and West, but to create a theoretical basis for a joint war with forces that destroy our lives, regardless of our geopolitical location. Adam Leszczyński also expresses his objections to the legitimacy of essentialising the experience of Central and Eastern Europe. In his opinion, this may contribute to perpetuating the ultimately infamous difference between the West and us - "still gray, still poor, and still authoritarian". The position of the Global East can also be problematic when it comes to its reception in the region itself. In this context, Tomasz Zarycki draws attention to the difficult fate of postcolonial theory in Poland, as well as the wider inclination of Eastern European societies to emphasize their uniqueness, which may destroy Müller's hopes of creating a single theoretical front under the banner of the Global East. The weakness of post-socialist academic institutions will not make it easier. The discussion ends with Martin Müller's response, in which he refutes some of the arguments put forward by his critics and advocates for "three ways to further intervene in the geopolitics of knowledge: revising existing concepts and theories (instead of emulating them), conducting comparative research beyond 
the Global East, and extending the theory to geographic areas other than Eastern".

By submitting this issue to your hands, we hope that the 10th anniversary of Theoretical Practice will be something more than a celebration of joint efforts and expression of gratitude for the work of many people who contributed to the journal over the years. We hope that the texts presented in this issue will set out further directions for the task of co-thinking and co-creating the future of the common.

\section{References}

Hardt, Michael, i Antonio Negri. 2009. Rzecz-pospolita: Poza wtasność prywatna i dobro publiczne. Tłum. Praktyka Teoretyczna. Kraków: Korporacja Ha!art.

Holloway, John. 2015. „Read capital: the first sentence: or, capital starts with wealth, not with the commodity." Historical Materialism 23(3): 3-26.

Marx, Karl. 1973. Grundrisse: Foundations of the critique of political economy. London: Penguin.

\section{Citation:}

Theoretical Practice. 2020. "The common: 10 years of Theoretical Practice." Praktyka Teoretyczna 4(38): 9-16.

DOI: $10.14746 /$ prt2020.4.1

Autorzy: Praktyka Teoretyczna

Tytuł: To, co wspólne: 10 lat Praktyki Teoretycznej 